\section{The dependent elderly: autonomy, justice and quality of care}

Edited by Luke Gormally, Cambridge, Cambridge University Press, 1992, 202 pages, $£ 24.95$ hc

Undoubtedly, when people are old, sick and dependent, they are in the ranks of the more vulnerable members of society. It is not always easy, however, to find solutions to their problems, and the all too common tendency to grasp at straws labelled 'neat' and 'facile' can, and probably often does, lead to a worsening of an already bad situation. Major ethical problems abound in this sphere and many are discussed in some depth in this book.

The first half is, for the most part, devoted to active and passive euthanasia. As one might expect, there is a good deal of discussion regarding the withholding and withdrawing of artificial nutrition and hydration. The book was published before the Tony Bland case hit the headlines, but there had already been widespread discussion of other PVS cases on the other side of the Atlantic, and the first of two contributions to this volume by Joseph Boyle is a chapter on that American debate. John Keown contributes some reflections on euthanasia in the Netherlands, and the living will also comes in for special treatment in a chapter from the pen of the editor, who makes three other contributions, including an introduction.

In the second half of the book, various other matters are discussed. These include the possibility of providing good quality long-term care without unfair discrimination, and the question of just what is required for good quality in long-term care of elderly people. In his second contribution, Boyle asks whether age should make a difference in health care entitlement. Also in the second half is a discussion by Michael Banner of the QALY (Quality Adjusted Life Year), which the editor describes succinctly as a health care economist's device 'for measuring the relative worth of different health care activities with a view to determining the distribution of resources'. The final chapter, with some concluding remarks on economics, justice and the value of life is provided by John Finnis.
There is a fair amount of comment about autonomy and justice, the problems attached to incompetence, the distribution of resources, and, as one might expect in this day and age, the part played by market forces in decision-making. I could not say that I agreed with everything in the book or that I found all arguments to be thoroughly convincing. It provides a fair amount of food for thought, however, and strikes me as a useful collection of contributions to several debates.

BERNARD HOOSE Lecturer in Christian Ethics, Missionary Institute London.

\section{There is nothing more I can do! An introduction to the ethics of palliative}

\section{care}

\section{David Jeffrey, Penzance, Patten Press, 1993, 116 pages, $£ 5.95$}

This is a short treatise by a doctor who trained as a general practitioner but who now works as a medical officer in a hospice. He has set out the philosophy of palliative medicine and intertwined contemporary medical ethics, highlighting the areas of dilemma. The book is aimed at general practitioners and primary-health-care team members involved in the care of the dying, although I think it will be most challenging to GP trainees, hospital doctors, and those training in oncology who feel the need for help in working through the statement: 'There is nothing more I can do'. They need guidance in the difficult decision-making required as to the appropriateness of certain treatments as the patient's illness progresses. They need to be able to recognize that while there is nothing more I can do as a surgeon or an oncologist, the patient needs continued care by the appropriate doctor and team who can address the issues of symptom control and psycho-social support. However, there can be difficulties, not mentioned by the author, even when the doctor recognizes the therapeutic limitations, because there will be patients who want and need to pursue active treatment options even though they know they are dying.

The book sets out clearly the areas of importance in patient care, and draws from the Beauchamp and Childress model of autonomy, beneficence, non-maleficence and justice. Alongside this the author demon-? strates how the palliative-care team can work and meet these goals in a personalized manner.

While the author mentions several potential moral dilemmas throughout the text, he deals in some depth with euthanasia. This is clearly a challenge to those of us working in palliative care, and Dr Jeffrey presents the argu- $\vec{O}$ ments against changing the law and current medical practice. However, I $\vec{\omega}$ think he ducks the issue when dealing with rational arguments from patients who are exhausted by their illness and $i$ can find no more value in living and wish to die. $\mathrm{He}$ argues that a request for euthanasia is beyond the bounds of personal autonomy, and infringes the 0

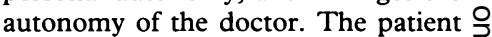
can exercise autonomy by taking his or her own life. This may resolve the $\bar{z}$ doctor's dilemma but is unrealistic and unhelpful for very ill patients at the end of their life. These situations remain very difficult but I do not think the doctor can avoid them by arguing that it is the patient's problens because this runs counter to the ethess. of palliative care which the rest of the book develops.

The book is easy to read and well referenced. I think most doctors and nurses will find it a stimulating read.

MICHAEL J MINTON Sir Michael Sobell House, The Churchill Hospital, Oxford.

\section{We can speak for ourselves}

Paul Williams and Bonnie Shoultz, London and Canada, Souvenir Press (Human Horizons series), 1982 (revised 1991), 252 pages, $£ 8.95$

This is a 1982 book with a 1991 foot- N note. As is traditional with the Human Horizons series, the book is good 0 value - but good value as an account of some aspects of the self-advocacy movement for people with learning $\mathscr{D}$ disabilities at the beginning of the 1980 s. As the authors themselves recognize in their footnote, the terminology and the references are dated; and those currently involved in or interested in self-advocacy will enjoy the early history of the movement, and perhaps find confirmation of their ideals. They will not find here the help 
with establishing or maintaining advocacy schemes which is provided by more recent do-it-yourself guides.

As history, this is closer to a contemporary document than a history textbook. The reader has to do his or her own selection, among a wealth of detail, about who did what and when and why in the early self-advocacy days in North America.

There is confusion in much discussion of self-advocacy between what is strictly self-advocacy, namely people being enabled to speak up in their own interests about their own past, present and future, and the much higher profile 'self-advocacy', which is really group advocacy by members of the group. This early study shows how the one thing blends into the other sometimes the public role helps an individual manage her own destiny more effectively. Sometimes getting a better grip on personal affairs helps someone move on to public affairs. Usually, the two things are mutually supportive.

While the 'criticism' that the People First Movement is based on more able people with learning disabilities is valid, We Can Speak For Ourselves illustrates the fact that few of the publicly prominent self-advocates are 'naturals'. All had to work very hard to become competent spokespersons. This means that there are messages for all those who work with and for people with learning disabilities. That message is about being conscious of the at-times shameful history of society's approach to people with learning disabilities; being conscious of the personal histories of those we are working with; and being open to the possibility that, verbally or not, they understand themselves better than we understand them. It is also about the certainty that unless we pool insights, we shall fail them, as we have so often failed them in the past.

BRIAN MCGINNIS Special Adviser, Mencap.

\section{Choices and conflict: explorations in health care ethics}

Edited by Emily Friedman, Chicago, USA, American Hospital Publishing Inc, 1992, 224 pages, $\$ 42$

Reviewers would do well to remember that generosity is a virtue for them as well as for the rest of humanity. The phenomenon of the clever, negative and archly self-aware review is disagreeably familiar. I hope I will not be thought to be encouraging this style of criticism if I say that I found reading this book a discouraging experience.

The book is an American Hospital Association publication which consists of twenty-eight essays, some new, most reprinted from journals, on a wide variety of topics in health care ethics. The editor has attempted to impose some shape on the collection by grouping the contents around six themes, but this thematic unity is more often than not spurious. Thus some of the essays under the heading of rationing seem to have little to do with that topic.

The authors include ethicists, physicians, lawyers and sociologists. The emphasis of most essays is ethical, though some are more factual and legal in orientation. The quality of the ethical thinking displayed here is, I have to say, somewhat lightweight. This lack of ballast springs in part from the absence of theoretical underpinnings for these moral reflections. When theory does put in an infrequent appearance, as with relativism and the debate between liberals and communitarians, it does so in a form so aetiolated as to be unhelpful. But this theoretical vacuum is not solely responsible for the sense of ethical flimsiness left by the book. There is a more general lack of intellectual penetration and imaginativeness that accounts for this feeling. There are exceptions. Essays by the Director of the Hastings Center and the executive editor of the New England fournal of Medicine are, as one would hope, a little more substantial. And it is a pleasure at last to discern some intellectual and philosophical sinews in a short essay on rationing by the philosopher Norman Daniels. But otherwise, reading this book is the literary equivalent of eating an indifferent blancmange which evaporates on the tongue, leaving little or no taste.

Books of this kind provoke more general reflections. In a scientific culture like ours there is a standing risk of science attracting more talent than ethics. The problems of the former seem so eminently more resolvable than the intractable problems of the latter. Such a tendency of thought was perhaps crystallized in the philosophy of logical positivism and has been more generally sustained by the prevalence in philosophy and outside it of the distinction between facts and values. The recent growth of interest in applied ethics amongst philosophers marks a welcome and significant weakening of this tendency. But one problem in doing applied ethics is how to transcend the sort of superficiality displayed in this book. Some think that the solution is to situate the practical issues in the context of competing moral theories, whose merits are then explored. Whatever the case for this, it does risk substituting intellectual paralysis for thoughtless conviction, not evidently a step forward, particularly for those who shoulder the responsibility of making the moral decisions on the issues in question.

At a moment when the teaching of ethics to health care professionals is beginning at last to be taken seriously, it is crucial that it not be perceived as an intellectually undemanding and lightweight option. If it is, able students will view its inclusion in the syllabus with irritation, and rightly so. The charge against this book, and others like it, is that they foster such a misconception.

WILL CARTWRIGHT Lecturer in Philosophy, University of Essex.

\section{Medicine betrayed: the participation of doctors in human rights abuses}

BMA working party, London/USA, Zed Books Ltd, 1992, 234 pages, $£ 9.95 / \$ 19.95$

This book is the report of a working party set up in 1990 by the British Medical Association under the chairmanship of Sir Douglas Black to look into the abuses of medical skills on prisoners throughout the world and to make recommendations as to how such abuses may be opposed and eradicated. This initiative is a great tribute to the British Medical Association in its role of forming and leading professional opinion, since the report clearly identifies how equivalent organizations in other countries have failed to speak out and condemn such practices, whether through inertia, tacit approval or direct political interference in their activities, and have thereby facilitated the development or continuation of such abuses.

The territory covered is familiar medical involvement in torture, the abuse of psychiatry for political purposes, the involvement of doctors in corporal and capital punishment and 